Ueber

\title{
die Infanterie.
}

\section{Vom}

\section{Marquis de Chambray,}

Obristlieutenant und Chef der Artillerie zu Vincennes.

Aus

dem Französischen übersetzt.

$$
\begin{gathered}
\text { Berli n, } 1824 . \\
\text { Gedruckt nnd verlegt } \\
\text { bei G. Reimer. } \\
\text { (Preis 10 Gr.) }
\end{gathered}
$$


